\title{
Can an Increase of Infrastructure Spending Contribute to Higher Potential Output in the Medium and Longer Term?
}

\author{
Maria Rita Pierleoni \\ Department of Economic Planning, Presidency of Council of Ministers, Rome, Italy \\ Email: m.pierleoni3@virgilio.it,mr.pierleoni@governo.it
}

How to cite this paper: Pierleoni, M.R. (2019) Can an Increase of Infrastructure Spending Contribute to Higher Potential Output in the Medium and Longer Term? Theoretical Economics Letters, 9, 2566-2592. https://doi.org/10.4236/tel.2019.97162

Received: August 12, 2019

Accepted: October 13, 2019

Published: October 16, 2019

Copyright ( 2019 by author(s) and Scientific Research Publishing Inc. This work is licensed under the Creative Commons Attribution International License (CC BY 4.0).

http://creativecommons.org/licenses/by/4.0/

\section{(c) (i) Open Access}

\begin{abstract}
This discussion on recent economic literature concerns some issues on potential output and related policy implications. It is not clear to what extent potential output growth has been affected by the recent crisis. Then the actual stabilization policies-based on the existence of output gaps and public debt sustainability-might not be appropriate to mitigate effectively cyclical fluctuations and to stimulate economic growth. The recent empirical evidence on the determinants of potential output-i.e. the origin of cyclical fluctuations-leads to a higher uncertainty on potential output measurement. Moreover the existing methods to estimate potential output present some weaknesses reducing reliability of the estimation results. Focusing on European case, the measure of potential output is considered as an useful guidance for policy. In particular, Stability and Growth Pact and Treaty on Stability, Coordination and Governance in the Economic and Monetary Union refer to the concepts of potential output, output gap and structural budget balance. Recently academics and some policy makers have criticized these measures and the related austerity policy because they worsened the economic situation. According to recent theoretical and empirical contributions it is important to rethink at the role of fiscal policy, focusing on fiscal stimulus and in particular on additional infrastructure spending because it can positively affect GDP as well as potential output. A part of this literature discusses extensively how public capital affects the economy. Under certain conditions such as a good institutional framework and sound projects, a higher spending on public infrastructure has a high economic impact.
\end{abstract}

\section{Keywords}

Potential Output, Cyclical Fluctuations, Persistence, Policy Implications, Additional Infrastructure Spending 


\section{The Origins of "Potential Output" Concept and Its Relation with Inflation}

According to the modern macroeconomic theory and in particular with the New-Keynesian view, the economic system may not be producing at its potential level. Potential output-defined as level of output achievable in absence of nominal rigidities-implies a full use of production factors with a given technology. At the level of potential output the actual rate of inflation is equal to the expected rate of inflation. When the actual output is not at the level of potential output, inflationary pressures occur. This relation is well explained by Jahan and Mahmud [1] as follows: the output gap is an indicator of the relative demand and supply components of economic activity. It measures the degree of inflation pressure in the economy: when the actual output is greater than potential output, prices will rise in response to demand pressure in key markets. On the contrary when the actual output is below potential output, prices will fall as a consequence of a weak demand.

The concept of potential output was born in 1962, when Okun spoke on the significance and measurement of potential GNP. Okun defined potential output as the maximum level of output achievable without creating inflation, linking the concept of maximum potential output with the criterion of an unemployment rate consistent with zero inflation. If current output diverges from potential output, output gaps emerge from over- or underutilization of productive capacities. In a scenario of negative gaps, the "attainable" level of entrepreneurial profits, household incomes, and long-term oriented investments in production facilities, installment, research and development is lower than a situation of full utilization of resources. A negative output gap might indicate a sluggish economy and portends a declining GDP growth rate and potential recession. Alternatively a positive output gap indicates an overutilization of resources, forcing businesses and employees to work beyond their maximum efficiency level. A positive output gap can spur inflation in an economy because both labor costs and prices of goods can increase. Potential output becomes, then, the main driver for stabilization policy because the existence of output gaps (positive and negative) implies macroeconomic inefficiency. According to Okun ([2] [3]), an effective stabilization policy mitigates cyclical fluctuations in the utilization of the current output potential and it furthers economic growth (Hauptmeier et al. [4]).

Before Okun's law, Phillips [5] - focusing attention on labour market in Great Britain-validated a negative relationship, stable in the long run, between the unemployment rate and the rate of change in nominal wage rates. In particular he demonstrated that wages regularly decreased when unemployment was high and sharply increased in a state of full employment. Two years later, Samuelson and Solow [6] substituted the change rate of nominal wages by the rate of inflation based on some assumptions on the increase in productivity and profit mark-ups. In doing so, they noted a stable trade-off between inflation and unemployment that determined a goal conflict between monetary stability and full 
employment. Consequently policymakers had to choose between two scenario: 1) low inflation coupled with high unemployment or 2) full employment coupled with high inflation.

The idea that full employment can only be possible at the cost of inflation was subject to some criticism by Phelps [7] and Friedman [8]. The authors stated that the concept of a Phillips curve, stable in the long run, was incompatible with rational economic behavior because what matters for employees was the real wage. Thus a certain and stable relation between unemployment and inflation did not exist. The authors affirmed that in a state of labor-market equilibrium the level of employment is compatible with any rate of inflation as long as nominal wages change in step. Followings this reasoning Friedman introduced the term of "natural rate of unemployment" as the level of unemployment that corresponds to theoretical full employment. Nevertheless, Friedman [8] argued that in the short run an increase of inflation might reduce statistical unemployment. He justified this situation with the presence of information asymmetries between employers and employees. Sometimes employers have information about the progression of prices in advance of their employees. In other terms workers and their representatives believe that nominal wage increases in phases of expansion correspond to a high purchasing power and accordingly raise labor supply. This situation is called "money illusion" and expansionary stabilization policy can generate inflation that is underestimated. At the end workers will learn from their mistakes and correct their expectations on future inflation on the basis of observed rise of inflation (under the hypothesis of adaptive expectations). In sum according to Friedman [8] and Phelps [7], an inverse relationship between inflation and unemployment can only prevail in the short run. The long-term Phillips curve is a vertical line at the natural rate of unemployment, so inflation and unemployment are unrelated in the long run. This implies that in the long run monetary policy is neutral with respect to real economic variables (Hauptmeier et al. [4]).

Based on Friedman's [8] definition of natural rate of unemployment-considered by most mainstream economists equal to natural rate of unemployment with non-inflationary unemployment or the NAIRU-the concept of potential output is implicitly defined as the level of national income compatible with the natural rate of unemployment. This is the basis of what Blanchard calls the "divine coincidence" according to which stabilizing inflation is equivalent to stabilizing the welfare-relevant output gap. In particular at the NAIRU rate, stable inflation goes along with the maximum employment which can be attained given the production capacity of the economy. Consequently any stabilization policy, aiming at displacing the unemployment rate from its natural location, causes only inflation gaps in the long run without any increase of employment. This implies also that the NAIRU is stable and independent of actual unemployment rates, i.e. its changes depend on changes in its structural determinants (Stirati [9]). 
This interpretation was empirically successful in the seventies but later empirical estimates of the NAIRU proved to conflict with the theory. Firstly, they were found to vary a lot, as testified by the creation of the new concept of a time-varying NAIRU ${ }^{1}$ (Blanchard [10]; Gordon [11]). Secondly, changes in NAIRU appeared to follow those in actual unemployment, in contrast with theory according to which NAIRU variations depend on changes in its underlying determinants. Reference [12] and other economists started addressing this problem back in the 1980s, developing models with hysteresis. Next Pichelmann and Schuh [13] stated that the observed trend increase in actual unemployment cannot be explained by changes in the basic determinants of equilibrium unemployment, then unemployment may be strongly dependent on its own history ("hysteresis"). Consequently current equilibrium unemployment is not independent of past actual unemployment and demand shocks end up having longer-term supply consequences (Pichelmann and Schuh [13]). Reference [14] questioned the dependence of the estimated NAIRU on underlying determinants such as labour market institutions. They investigated the relation between estimated NAIRU and labor market institutions for 20 OECD countries over the past forty years, showing that: 1) this relation does not appear to be stable over time and 2) the most comprehensive available measures of institutions and policies can only account for a minor part of the differences in the evolution of unemployment across these countries.

Reference [15] show that a large negative output gap can produce persistent effects on the level of potential output, via hysteresis effects in the labor market or reduced investment lowering the capital stock. Reference [16], in its advice to the UK government, found that hysteresis from unemployment effects reduces potential GDP by 0.1 percent for each 1 percentage point increase in the cumulative annual output gap. Reference [17] — based on data for 20 industrial countries in the period 1960-2013 - and Blanchard [10] — focused only on the United States-reached the following empirical results: 1) it exists a hysteresis in output, implying that Central Bank policy should focus not only on price stability but also unemployment (only price stabilization measures may have significant costs in terms of high and persistent unemployment). 2) It exists a relation between the level of unemployment and the level of inflation and it goes from the first to the second; this relation looks like the old downward sloping Phillips Curve and it is weak as showed by large standard error of residuals. 3) The Phillips Curve is currently rather flat, implying that large changes in the unemployment rate are necessary to bring about significant changes in inflation.

From the above discussion emerges quite clearly that market forces themselves do not bring output and employment to their natural path, then stabilization policies are needed. One of the main driver of these measures is the concept ${ }^{1}$ The result of a time-varying NAIRU implies that: 1 ) the rate depends on the actual path of unemployment, that is a function of changes in aggregate demand, and 2) changes in the unemployment rate tend to be persistent; consequently after a recession (or a boom) the unemployment rate does not return to an equilibrium rate which is determined independently of the recession (or boom) itself. 
of potential output that is the parameter to take into account for mitigate cyclical fluctuations and stimulate economic growth. In a more general way, in defining stabilization measures, it is important to consider the following facts: 1) the concept of potential output defined as the level of national income compatible with the natural rate of unemployment is not validated by recent empirical results, then it is necessary to better investigate the relationships underlying the concept; 2) the so called "divine coincidence", according to which stabilizing inflation is equivalent to stabilizing the welfare-relevant output gap, it does not happen as showed by the recent empirical results, and 3) monetary policy might not be successful to pursue: a) unemployment and inflation targets and b) re-start economic growth ${ }^{2}$.

That said the paper provides an overview of both theoretical and empirical recent literature about the concept of potential output, with a special focus on European case. In particular some issues on potential output are discussed because they have direct implications on defining appropriate economic policies. According to this literature, fiscal policy, as a macroeconomic tool, should be revised also because some theoretical assumptions-such as the relations between potential output, output gap, unemployment and inflation-do not seem to occur in reality as showed by empirical evidence. Given the inability of economic system to generate persistent growth, there is a growing consensus that the most appropriate policy response should be based on fiscal stimulus and in particular on additional infrastructure spending.

The article is organized as follows. Section 2 discusses the underlying relationships to potential output and the related policy implications. Section 3 describes the alternative methods of estimating potential output. Section 4 focuses on potential output of Euro area after the recent crisis and the policy response of European Institutions. Section 5 discusses the relation between potential output and additional infrastructure spending, taking into account also the recent empirical contributions focused on Euro area. Finally, Section 6 presents conclusions.

\section{The Underlying Relationships to Potential Output and the Related Policy Implications}

Potential output can be considered as an optimal benchmark for the actual GDP which can rise or fall according to cyclical fluctuations. As explained before a positive output gap happens when demand is very high while a negative output gap occurs when economic system is not producing at full capacity, due to weak demand.

As the output gap occurs, implications for monetary policy and/or fiscal policy emerge. For example when actual output falls below its potential, a Central

${ }^{2}$ At this regard several studies showed that interest rates have little or no impact on investments (Blanchard [18]; Chirinko [19]; Ford and Poret [20]; Khotari et al. [21]; Sharpe and Suarez [22]) while other works pointed out that changes in aggregate demand are the main driver of investments (Girardi and Pariboni [23]; Onaran e Galanis [24]; Schoder [25]; Wen [26]). 
Bank could low interest rates to rise demand and prevent a fall of inflation below the central bank's inflation rate target. On the contrary when output rises above its potential level a Central Bank could decide to raise interest rates to control upward pressure on inflation. Also Governments, through fiscal policy, can act to close the output gap. In case of a negative output gap, an expansionary fiscal policy-i.e. an increase of government spending or a reduction of taxation-can be applied. Alternatively when there is a positive output gap, an contractionary fiscal policy-i.e. a reduction of government spending or an increase of taxation-can be adopted to reduce demand and to combat inflation (Jahan and Mahmud [1]).

As noted by Jahan and Mahmud [1] estimating potential output and output gap is not so clear and immediate, given the uncertainty of underlying relationships in the economy. One of the issues addressed by the economic literature is why recovery has been very slow since the 2008 crisis, and there is still no sign of a return to the GDP forecasts made prior to 2008. In particular the recent economic studies show that after the 2008 recession, estimated potential output has declined and the estimated NAIRU has increased in most countries. Others empirical works have provided evidence, based on the experience of many countries over a long time period, that recessions have persistent effects on the path of GDP. Then it seems not plausible the notion that GDP would return to an independent, supply determined trajectory (Martin et al. [27]; Ball et al. [28]; Ball [29] [30]; Blanchard et al. [17]; Cerra and Saxena [31]; Fatàs and Summers [32]; Reifschneider et al. [33]). In other terms, fluctuations tend to be associated with persistent changes in GDP trajectories, as a result the return to an independently determined GDP trend must be extremely slow (i.e. beyond the horizon time assumed for cyclical fluctuations and economic policy). This evidence has been interpreted by the "real business cycle" literature as the following: cycle and trend are determined by the same factors, i.e. supply determined. At the same time, on the basis of other empirical results which show that is aggregate demand to drive fluctuations (Fazzari et al. [34]; Gali [35]; Lorentz [36]; Girardi [37]), persistent changes in GDP trajectories can be determined by aggregate demand, i.e. cycle and trend are driven by aggregate demand. According to most of this literature, the persistence occurs only from negative shocks, which generate higher equilibrium unemployment and lower potential output. In this new equilibrium any attempts to restore output and lower unemployment by means of aggregate demand would determine an high and accelerating inflation (Girardi et al. [38]). In contrast with this latter result, Girardi et al. [37] -investigating the effects of positive demand shocks through the selection of 94 episodes of demand expansion (i.e. an increase in autonomous demand) in a panel of 34 OECD countries between 1960 and 2015-shown that a positive demand shock determines: 1) a persistent effect on the GDP level; 2) a persistent reduction of unemployment level; 3) an increase in labour participation, employment and the capital stock and 4) a positive and quite persistent effects on productivity. In other words, their results show that production, employment and unemployment are not in- 
dependent by aggregate demand even in the long run. Another important result concerns the capital stock. The authors show that aggregate private investment largely depends on lagged GDP, and little, if at all, on interest rate.

Subsequently Girardi et al. [38] — referring at most recent empirical literature focused on potential output, unemployment and hysteresis-discussed the circumstances in which changes in aggregate demand can have an appreciable persistent effect on aggregate supply. In doing so they offered an explanation about the reasons of the so called "secular stagnation" (i.e. inability to generate persistent growth (Summers [39]; Teulings and Baldwin [40])), and at the same time they gave some advices in terms of policy. According to the authors, the literature on secular stagnation has identified three (separate or interlinked) factors for explaining these phenomena: 1) a negative equilibrium real interest rate; 2) slow (or even negative) growth due to structural factors, such as demographic and technological trends; and 3) hysteresis. Within the literature on secular stagnation, "hysteresis" or "persistence" appears to be the best line of interpretation of the current situation (Blanchard et al. [17]; Martin et al. [27]; Cerra and Saxena [31], Guajardo et al. [41]; Jordà and Taylor [42] among others). At this regards, Girardi et al. [38] affirm that "the dependence of capital formation on aggregate demand growth appears to be the most convincing and empirically supported explanation of the persistent effects on GDP resulting from shifts in aggregate demand". Based on the evidence that aggregate demand expansions determine persistent effects on GDP, capital stock, participation and employment, the authors conclude that fiscal stimulus would be the most appropriate policy response to counteract secular stagnation. Their results are in line with other recent literature (Blanchard et al. [43]; Summers [39] and [44]; Turner [45]) that sustains the importance of fiscal stimulus, given that hysteresis is based on the effect of aggregate demand on capital formation.

As stated by Blanchard et al. [43] after the crisis, the role of fiscal policy, as a macroeconomic tool, has been revised for two main reasons. First, given that monetary policy, including credit and quantitative easing, has largely reached its limits, policymakers have to use fiscal policy. Second, given that the recession is not totally overcome, the fiscal stimulus might have time to produce beneficial impacts, despite the implementation lags. In this context the policymakers have potentially more instruments at their disposal with respect the scenario before the crisis. The authors point out that the main goals to achieve should remain the same-i.e. stable output gap and stable inflation-also if the secondary goals are higher, including the composition of output, the behavior of asset prices, and the leverage of different agents. Thus, the challenge for policymakers consists to find the best way for applying instruments of economic policy (Blanchard et al. [43]).

The literature on fiscal stimulus was defined by Furman [46] as a "New View" of fiscal policy. He argues that when monetary policy is at the effective lower bound, fiscal policy may even be more effective than previously realized. This can occur given that monetary policy-through interest-rate channel or ex- 
change-rate channel-will not even partially offset fiscal policy. In this context fiscal policy might also determine a crowding-in additional private investment. In other words, an expanded aggregate demand raises growth rates and thus increases investment growth, as predicted by the standard accelerator model for investment (IMF [47]; OECD [48]). In particular in an economy with a large output gap, fiscal expansion can expand private investment by raising inflation expectations, which would lower real interest rates.

The above discussion - focused on empirical evidence of the last decadeemphasizes the following results: 1) cyclical fluctuations have persistent effect on GDP trajectories, and consequently on GDP trends which represent a measure of potential output; 2) these cyclical fluctuations seem to be driven by aggregate demand shocks (also positive), in particular aggregate demand expansions bring about persistent effects on GDP, capital stock, participation and employment at the cost of an extremely short-lived and moderate increase in inflation ${ }^{3}$; 3) on the basis of this empirical evidence, a part of recent economic literature sustains the importance of fiscal stimulus as the most appropriate policy response to secular stagnation.

\section{Alternative Methods of Estimating Potential Output}

At this point of the discussion I want to pay attention also at technical aspects concern potential output, i.e. how it is possible to estimate it. To estimate potential output it is assumed that output can be divided into a trend and cyclical components. The trend represents a measure of the economy's potential output while the cycle is considered as a measure of the output gap. Consequently estimating potential output means to estimate trend, removing the cyclical changes. These cyclical changes-i.e. fluctuations-reflect movements in the trend components of inputs, such as: 1) labor (two key concepts connected to the labor component are the NAIRU and the NAWRU-non-accelerating wage rate of unemployment), 2) total factor productivity (TFP) and 3) capital (also if is often assumed that all capital is trend capital). According to European Parliament [49], the main goal of using potential output estimates and related concepts is to enable a counter-cyclical economic policy, "i.e. avoiding further inflationary pressures in boom times and support demand in contractionary periods". However the measurement of potential output is not observable, and it depends on models and assumptions applied to estimate it. This means that different models and assumptions produce different estimates and economists evaluate the performance of the applied methodologies by looking at revisions of the estimated values over time.

Generally, there are two main directions for estimating potential output. Firstly, there are statistical non-parametric and univariate techniques such as filtering which decompose time series into trend and cyclical components. The advantage of such methods is their relatively simple implementation. On the ${ }^{3}$ At this regards, Blanchard [10] stated that some change in unemployment could occur without consequences for the level of inflation. 
other hand, these methods basically just filter out some frequencies from the data and therefore are not able to catch any structural changes within the sample. Within statistical techniques, the most used filters are the followings: 1) the HP filter, based on the work by Hodrick \& Prescott [50] and 2) the Baxter-King (BK) filter, settled by Baxter \& King [51]. The main drawbacks of these methods are discussed by Anderton et al. [52]. Firstly, using the filtering to estimate trends implicitly creates assumptions about the trend's (HP) or lower frequencies' (BK) existence. Consequently there is a possibility of a mistake in identifying the correct cycle, as the filter may not define the actual one. Secondly, these methods are highly dependent on the choice of parameters ${ }^{4}$ that is made directly by researcher. The choice is arbitrary to some degree, even though there are "best practice" guidelines on how to proceed. The third major drawback comes from the fact that the univariate methods suffer from very large end sample biases. Filtering is basically a non-parametric method and as so it has poor forecasting reliability.

An alternative method to estimate potential output is based on economic theory and in particular on the production function. According to production function method, potential output is the level of production (typically in terms of value added) at which the factors of production are fully employed, at least at the maximum level compatible with the NAIRU or NAWRU measures. This approach allows for a more direct link to sources of structural information and for an easier interpretation of the source of changes in the output gap or potential output (Anderton et al. [52]). However, there is additional uncertainty in these models. Total factor productivity and Non-accelerating inflation rate of unemployment (NAIRU) or alternatively NAWRU components of the function are themselves unobservable. These components are often obtained by statistical filtering which puts the production function approach to a criticism, as the uncertainty is shifted to the sub-steps. In a more general way, with production function approach, as with other methods, is impossible to evaluate in a formalized manner the degree of uncertainty of potential output estimations. An important advantage of this method is its reliability at sample end point (Cotis et al. [53]). For what concerns the functional form the most used specification is that of Cobb-Douglas or, alternatively, the constant elasticity of substitution function. Both usually include three factors of production: 1) capital, 2) labor and 3) total factor productivity. The view given by this approach is structural as it is based on a supply side model that can help to identify the underlying contributions of respective factors as well as explain the forces underlying developments of growth in the medium term.

The classical production function considers the level of output $(Y)$ to be a combination of two factor inputs, namely labour $(L)$ and capital $(K)$, where each

${ }^{4}$ For example "lambda" in Hodrick-Prescott filter which is the weighting parameter and it controls the smoothness of the trend line. High values of lambda reduce the sensitivity of a filter to short-run fluctuations and in the limit it should converge to the mean growth of the output during the specified period. On the other hand, zero lambda results in the perfect fit of trend to the actual values of the series. 
factor input is corrected for the degree of excess capacity $\left(U_{L}, U_{K}\right)$ and adjusted for the level of efficiency $\left(E_{L}, E_{K}\right)$. In addition to the labor and capital inputs, output is expected to be affected by total factor productivity (TFP), which is measured as the Solow residual (Anderton et al. [52]).

$$
\begin{gathered}
Y=\left(U_{L} L E_{L}\right)^{\alpha}\left(U_{K} K E_{K}\right)^{1-\alpha}=L^{\alpha} K^{1-\alpha} \mathrm{TFP} \\
\mathrm{TFP}=\left(E_{L}^{\alpha} E_{K}^{1-\alpha}\right)\left(U_{L}^{\alpha} U_{K}^{1-\alpha}\right)
\end{gathered}
$$

Under the assumption of constant returns to scale and perfect competition, Equation (1) and Equation (2) imply that the output elasticities of the two factor inputs equal the factor shares in output, with $\alpha$ representing the output elasticity of labor and $1-\alpha$ that of capital. The Cobb-Douglas production function also assumes that the elasticity of substitution between labor and capital is 1 . To calculate the potential level of output, it is necessary to calculate the trend components of the various inputs which are defined as followings (European Parliament [49]):

- Capital that is a function on: 1) past capital stock, 2) investments, and 3) depreciation rate, (ranging from $1 \%$ for computer hardware and equipment to $30 \%$ for housing). Thanks to its smoothness and stability, capital is identified with trend capital.

- Labor that is expressed in terms of hours worked; it is determined as a product of population projections, participation rates, hours worked and the non-accelerating wage or inflation rate of unemployment. Trend labour is the product of its trend components.

- Total factor productivity (TFP) that measures productivity growth (such as technology improvements); it is estimated as a difference between output and input components. The trend is obtained by filtering its time-series. TFP is an indirect indicator because it represents a residual of unobservable quantities, then it is very difficult to estimate.

Other approaches include the unobserved components method and the structural vector autoregression approach or SVAR. The unobserved components methods (Beveridge-Nelson [54]) decomposition, univariate unobserved components model, bivariate unobserved components model and common permanent and temporary components) estimate unobserved variables such as potential output and the NAIRU, using information from observed variables. The SVAR approach is based on the method developed by Blanchard and Quah [55] to distinguish between the permanent and transitory components of output using a structural vector autoregression with long run restrictions. The unobserved components approach has the advantage that relationships between output, unemployment, and inflation can be specified (Cerra and Saxena [31]). The relationships are first written in state-space form, that is a general way of representing dynamic systems (which include measurement and transition equations). The observed variables are specified as a function of the unobserved state variables in the measurement equation while transition equation specifies the autoregressive 
process for the state variables. When a dynamic time series model is written in a state-space form, the unobserved state vector can be estimated using the Kalman filter ${ }^{5}$. In general this approach has the disadvantage of requiring considerable programming, with ensuing difficulties in debugging the model and interpreting the results. Moreover results are often sensitive to the initial guesses for the parameters (Cerra and Saxena [31]). Based on the traditional Keynesian and neoclassical synthesis, the SVAR method identifies potential output with the aggregate supply capacity of the economy and cyclical fluctuations with changes in aggregate demand. Within this approach the Blanchard and Quah [55] method-based on a vector autoregression (VAR) for output growth and unemployment-identify structural supply and demand disturbances according to the hypothesis that the former have a permanent impact on output, while the latter can have only temporary effects on it. The analysis can be extended to consider also temporary nominal shocks by inserting also a price variable (Cerra and Saxena [31]).

Within the existing methods, the most used by international Institutions is the production function approach, that is also widely applied by central banks (Havik, et al. [57]). For what concerns specific technicalities adopted by international institutions, it was observed that:

1) The European Commission estimates are from the regular projection exercises and from the assessment of stability/convergence programmes of $\mathrm{EU}$ Member States (Ufficio Parlamentare di Bilancio [58]). The methodology is based on a Cobb-Douglas production function, in which the trend labor component is derived from population projections, trend participation rate, trend hours worked and NAWRU. The trend TFP is obtained by means of a bivariate filter, augmented with a capacity utilization measure. This is supplemented, for the longer term, by a number of considerations, e.g. on cross-country convergence, etc.

2) The IMF estimates are not based on any "official" method, and may incorporate judgement by the relevant country desks. However, for the euro area countries, some version of the production function approach is usually involved (Epstein and Machiarelli [59]; Konuki [60]).

3) The OECD estimates are based on a similar methodology, including a Cobb-Douglas production function with labor, physical and human capital and multi-factor productivity (the equivalent of TFP) as factors as well as an exogenous trend. OECD estimates consider the Kalman filter to define the NAIRU (Cotis et al. [53]).

As discussed above, the existing methodologies, including production function approach, present some drawbacks which can affect the estimation results of potential output. At this regards Coibion et al. [61] affirm that much work have to be done to create a better measure of potential GDP. According to the authors some of the existing methods seem potentially underused, consequently they offer the following suggestions to ameliorate their utilization: 1) using addi${ }^{5}$ For technical details: Harvey [56]. 
tional macroeconomic variables and restrictions to better identify supply and demand shocks rather than relying on univariate processes; 2) supporting public estimates of potential GDP with information about private sector forecasts which are more successful at isolating supply shocks from demand shocks and 3) limiting excessive use of model-averaging, or at least to exclude, among the class of models used, simple approaches like HP-filters since these mechanically induce movements in estimates of potential after cyclical demand-driven fluctuations.

The general weakness of the estimation methods reduces the reliability of the potential output estimations. This issue should be take adequately into account when rules or economic policies, mainly based on potential output measure, are defined.

\section{Potential Output of Euro Area after the Crisis and the Policy Response of European Institutions}

After the recent crisis the crucial problem is the inability to generate persistent growth (Summers [39] and [44]; Teulings and Baldwin [40]). This scenario may have been worsened also by a tight fiscal policy which has been dominated by consolidation measures focused to expenditure cuts especially for investments/infrastructures. According to Summers [44] an increase in public investment represents the key to restore reasonable growth and it is hard to make a rational case against a substantial increase in public investments in Europe and in United States.

Until today-that is a long time after the crisis-negative output gaps and employment gaps are not still closing. For example taking into account the United States and Euro area, Anderton et al. [52] observe that the crisis has affected mainly labor and capital as a components of potential output (Anderton at al [52], figure 22). In particular, for what concerns the Euro area the decline in labor contribution was largely caused by the considerable rise in structural unemployment. In both areas the decline of capital stock was a consequence of lower investments which may have had a constraining effect on the supply capacity of the economy and hence on potential output growth in the longer run. Intuitively, lower investment leads to a permanently lower capital stock. To the extent that new capital also embodies technological improvement, lower investment may also be associated with lower TFP growth. In addition to a reduction of investment growth, the rate of capital scrapping and the life span of capital assets have also been affected by the crisis, in particular in the Euro area. Moreover in the Euro area there is still an excess of savings which requires real interest rates to be low or negative for an extended time in order to support the return of output to potential and the labor market to full employment (Anderton et al. [52]).

While potential output growth in the Euro area remained weak in 2011-12, in the same period in United States it started to recover. For the future a faster re- 
covery in US potential output with respect that of Euro area is expected. The difference is explained by higher capital and TFP contributions as well as a substantial difference in the projected labor contribution. Several factors could explain this divergence: 1) the more flexible nature of the US economy, allowing faster labor market adjustment; 2) an US fiscal policy more prone to support activity with respect those in euro area where the sovereign debt crisis and the associated surge in uncertainty had a direct negative impact on economic activity, e.g. via cuts in public infrastructure investment; 3 ) an US bank credit standard on mortgages and loans to non-financial corporations that, starting from the middle of 2010, became less tight with respect to the euro area. In general terms, according to Anderton et al. [52]: "it is not yet clear to what extent potential output growth has been affected by the crisis and this assessment is more uncertain than in previous downturns, owing to the severity of the slowdown in activity and of the imbalances that had accumulated prior to it". Moreover as showed by recent empirical literature, the determinants of potential output can be originated by both demand and supply side and this evidence contributes to increase uncertainty on the actual measurement of potential output.

Given these issues, today the concept of potential output and its measurement should be taken with cautions by Institutions that adopt stabilization policies. In other words, given the uncertainty surrounding estimates of potential output it became more difficult to judge both the current degree of slack in the economy and the growth and inflation prospects for the economy. As a result the definition of appropriate monetary and fiscal policies, based on potential output and output gap, is more difficult. However the European institutions continue to consider the concept of potential output and NAIRU as an useful guidance for policy. For instance they are used to assess structural budget deficit constraints. In particular, the Stability and Growth Pact (SGP) and related secondary law widely refer to the concepts of potential output, output gap and structural budget balance (SBB). Moreover the Treaty on Stability, Coordination and Governance in the Economic and Monetary Union (TSGC) refers to a fiscal targets which are expressed in terms of structural budget balances (European Parliament [49]).

Within the SGP, the fiscal medium-term objective (MTOs) for euro area Member States (and Member States belonging to the Exchange Rate Mechanism-ERM II) are specified to vary within a range between -1\% of GDP and a balance or surplus. The fiscal medium-term objective (MTOs) are updated every three years, or in case of major structural reforms. Within of MTOs two typologies of countries are identified: 1) Countries under the preventive arm of the SGP, not having achieved their MTOs, should respect an adjustment path of their SBB towards it, with an annual improvement of $0.5 \%$ of GDP per year as a benchmark. In this case the expenditure benchmark rule has been introduced to complement the MTOs. This rule is defined in terms of potential output estimates and it limits the growth rate of government spending. In particular it establishes that a spending growth rate beyond the medium-term potential eco- 
nomic growth rate must be compensated by additional discretionary revenue measures. 2) Countries under the corrective arm of the SGP, i.e. those in excessive deficit situations, should improve their SBB of at least $0.5 \%$ of GDP per year as a benchmark.

In its communication on January 2015, the European Commission introduced the output gap in one of the flexibility clause used to assess the adherence of a Member State to the SGP. This clause takes into account "good" and "bad" economic times and to this aim, the Commission defines five "output gap intervals" in order to assess the annual fiscal adjustments towards the MTOs. The structural budget balance represent also the main element of the TSGC. All signatories of the TSGC with a debt ratio well below $60 \%$, and/or facing low risks to the sustainability of public finances, are committed to set a MTO of at least $-1.0 \%$ of GDP; while signatories from the euro area with a debt ratio above $60 \%$, or facing risks to the sustainability of their public finances, are committed to set a MTO of at least $-0.5 \%$ of GDP. Under the terms of the TSGC, all signatories are committed to: 1) approving national binding law rules, by observing the provisions of the preventive arm of the SGP intended to limit their structural deficits, and ii) defining a correction mechanism that would be triggered automatically, at national level (European Parliament [49]).

According to the European Commission, structural fiscal balance indicators are very useful, albeit not perfect, indicators of the fiscal policy stance. In practice, measures of the structural fiscal balance mostly depend on measures of the output gap and on the government aggregate tax or expenditure to GDP ratio. Given their reliance on the output gap, estimates of the structural fiscal balance are rather uncertain, while measures of its changes over time are generally considered to be more robust (Economic Policy Committee [62]). Recently, the concept of structural balance, the related indicators, and the methodology used to estimate it, have been subject to some criticisms by EU and the Member States, in particular as regards their reliability and transparency.

At this regards I cite: 1) Deutsche Bundesbank study [63], focusing on G7 countries, gives warning of the high degree of uncertainty of output gap estimates, and expressing doubts on the suitability of such estimates in economic policy. 2) In 2014 European Central Bank mentioned the problem posed by the stability of output gap estimates and of their revision, by comparing the estimates of 2007 output gaps made at different points in time. 3) In 2016 the Ministers of finance of eight Member States (Italy, Spain, Latvia, Lithuania, Luxembourg, Portugal, Slovenia and Slovakia) sent a letter to the Commission, expressing their concerns regarding the estimation of potential output and asking the Commission to extend the length of its forecast horizon from two to four years (European Parliament [49]).

In a more general perspective, Furman [46] discusses other aspects which should lead to rethink the stabilization policy in Euro area. In particular, the Stability and Growth Pact (SGP) - that represents an attempt of fiscal policy coordination-is asymmetric since it can compel deficit reduction but cannot 
compel fiscal expansion. The European Central Bank (ECB), managing macroeconomic policy in Euro Area, might not able to address-by means of monetary policy-shocks, which seem to be persistent and affect the entire Euro area (also because the actual monetary policy runs into limits). The actual European institutional structure acts as barriers to effective policy, amplifying shocks rather than dampen them. At this purpose Furman [46] suggests to undertake more countercyclical fiscal policy at the Euro area level or at least ameliorate coordination of national fiscal policy by means of a revision of the SGP or with a new multilateral agreement. Within countercyclical measures, Furman [46] includes an increase in infrastructure funding through, for example, the European Investment Bank.

Fiscal rules of the Stability and Growth Pact have been critized also because they do not consider the so-called "golden rule of public finance", which excludes public investments from the deficit ceiling (Blanchard and Giavazzi [64]). At this regards some studies argue that the composition of expenditure cuts may critically influence fiscal consolidation processes put into action to respect the SGP rules. In particular Hakhu et al. [65] investigate the relationship between investment spending and debt financing in the EU. They find a negative relationship between public capital expenditure and public debt. According to their empirical results, strengthening the sustainability of EU public finances can be obtained by rising public expenditure in assets, such as, investments in technology and infrastructures.

\section{Potential Output and the Role of Public Infrastructure Expenditure}

As discussed before the cyclical fluctuations can origin by supply and demand shocks. Moreover not only supply shocks have a permanent effect on GDP and not only negative shocks can be persistent. This evidence contributes to increase the uncertainty on the actual measurement of potential output. Institutions, such as those European, which consider potential output as useful guidance for policy should pay more attention to these results and their implications. Moreover to restore economic growth, it is necessary to redefine policy response. At this regards a part of recent economic literature sustains the importance of fiscal stimulus, including additional infrastructure spending. In what follows I discuss the relation between infrastructure spending and economic growth and examine some recent empirical studies focused on Euro area.

Generally speaking, the economic literature (Aschauer [66]; Kamps [67] and [68]; IMF [69]; De Jong et al. [70]) has proven that an increase of public spending and in particular on infrastructures can positively affect the economy in two ways. In the short term it boosts aggregate demand through the short-term fiscal multiplier, also by potentially crowding in private investment, given the complementary nature of infrastructure services. As stated by Fournier [71]: "If public and private capital are complementary (e.g. roads that connect enterprises), 
higher public investment can spur private investment. This corresponds to cases in which the social return is above the private return...”. Over time, there is also a supply-side effect of capital expenditure when it turns into effective capital formation, that is productive machinery and, because of the role of government, in an increase in the production capacity of the infrastructures or of other public goods put into operation. This effect (if there is a good governance and investment was properly selected by cost benefit analysis) could be greater than the government-backed expenditure for its implementation (IMF [69]).

Fiscal expansions-including infrastructure spending-could have also large positive spillovers, especially when they are internationally coordinated. The size of spillover effects will depend on the size of the country or region concerned and its openness (Romp and De Hann [72]). A fiscal expansion can increase demand in both the domestic economy and the economies of its trade partners; in a more general way shocks to demand can spill even more swiftly and strongly across borders when aggregate demand is weak and interest rates are low (Furman [46]). Reference [73] found that countries or regions engaging in an individual permanent fiscal expansion worth $1 \%$ of GDP face rising deficits and debt levels. On the contrary when fiscal expansion is coordinated across all regions, additional growth reached at least $1 \%$ in each region, cumulating to an additional 2.3\% in global growth, while the debt-to-GDP ratio reduced everywhere. According to Romp and De Haan [72] another reason because public capital may affect positively economic growth, is suggested by the new economic geography (Krugman [74]; Holtz-Eakin and Lovely [75]; Venables [76]; Fujita et al. [77]). This strand of research considers transport costs a central determinant of two choices: 1) the location and scale of economic activity and 2) the pattern of trade. Therefore infrastructures-and in particular more transport infrastructure-play an important role on defining the size of the market, because producers can cluster together in one central region. In such way the producers may benefit of specialization and economies of scale.

The efficiency of investment is central to determining how large these effects will be. Reference [78] found a small and non-significant long-term effect of large infrastructure projects and public capital increases in low-income countries. The author discussed on the quality of investment programs implemented on selected low-income countries. He noted that these programs suffered of the following problems: 1) incentive problems, 2) agency problems, 3) a pervasive avoidance of rational analysis and 4) even difficulty obtaining or collecting the critical data. As a result the crucial information-which normally constitute the basis on investment choices-were unavailable. Then the final result was a low-quality of the selected investment projects. Reference [79] investigate the nexus between efficiency, public investment and growth. They found with a standard model that both efficiency and rate of return of public capital need to be considered together in assessing the impact of increases in investment. Changes in efficiency have direct and potentially powerful impacts on growth. 
They suggested then to "investing in investing" through structural reforms that increase efficiency leading to a very high rate of return. Reference [80] highlights the role of public investment for economic growth and the policies that governments should adopt to improve public investment efficiency. Inefficiencies in the investment process, such as poor project selection, implementation, and monitoring, can result in only a fraction of public investment translating into productive infrastructure, limiting the long-term output gains. Reference [71] sheds light on the long-term effects of public investment, estimating the average effect and providing some insights on the specific circumstances, which make public investment particularly effective. Considering data on OECD countries, the most important findings are the following: 1) increasing the share of public investment in total government spending yields large growth gains; 2) these effects are highest in sectors that are associated with large externalities, such as research and development or health, and they are lowest in countries where the public capital stock is already high such as Japan; 3 ) a spending shift towards public investment, away from other spending, would also speed up the convergence of lagging countries towards the income of the most advanced economies; 4) in terms of economic policies, governments should implement sound public investment policies (provide the right incentives, carry out cost/benefit analysis underpinned with good data) and focus on sectors with high externalities, because public investment is a lever to boost growth in the long run. Reference [69] concluded that well-planned fiscal expansions will more than pay for themselves. Specifically, the IMF found that infrastructure investment would have substantial positive impacts on gross domestic product and those impacts would be large enough to reduce debt burdens. Reference [15] — considering a depressed economy characterized by a form of negative hysteresis-found that a debt-financed increase in public investment as a share of potential GDP leads, in the short run, to a change in the debt-to-potential GDP ratio. However, in the long run these effects are countered by the emergence of supply effects i.e. from the increase in productive capacity, and productivity that efficient investments will generate. At the end the final result is positive and the expansionary fiscal policy is self-financing. Reference [73] found that a permanent increase in government investment of $1 \%$ of GDP increases growth through permanently increasing investment and consumption. This fiscal spending creates future fiscal space $^{6}$ through increasing government revenue and reducing the debt-to-GDP ratio (Furman [46]).

In what follows I focus the discussion on the most relevant empirical contributions which analyze the role of infrastructure spending on GDP as well as on potential output of Euro area countries. Reference [81], focusing on European case during the period 2008-2014, argued on the "negative loop" determined as a consequences of the interaction between an overly pessimistic view on potential ${ }^{6} \mathrm{~A}$ needed condition for a country to obtain a better fiscal space is the existence of credible political system that is capable of making firm, long-term commitments, since upfront fiscal expansion can be combined with medium- and long-term fiscal consolidation (Furman [46]). 
output among policy makers and the effect of fiscal policy focused mainly on contractionary measure. These measures determined a reduction in potential output that validated the original pessimistic forecasts and led to a second round of fiscal consolidation. The author shows that for many European countries the succession of contractionary fiscal policies "was likely self-defeating as the negative effects on GDP caused more damage to the sustainability of debt than the benefits of the budgetary adjustments". In other words the effects of contractionary fiscal policy (adopted mainly for the purpose of public debt sustainability) on output fed into more pessimistic views on the future leading to an additional fiscal consolidation. These damaging effects affected the estimates of potential output that were highly pro-cyclical: "if cyclical events lead to immediate reductions to long-term projections of GDP, it might lead to even more contractionary fiscal policy and further negative effects on output". The author suggests that for a good design of fiscal policy, in particular when sustainability is an issue, governments have to define accurately potential GDP and output gap. Reference [82] showed that the negative effects of contractionary fiscal policy become permanent via hysteresis effects during the fiscal contraction 2010-2011 in Europe. The authors affirm that "in the presence of hysteresis, not only we are underestimating the effects of fiscal policy on output, but we might fall in a vicious cycle that we call the fiscal policy doom loop". These contractionary measures were applied in almost all advanced economies for which the capital stock was declining. In particular as discussed above, for the two big areas-the United States and Euro area-the decline of capital stock was a consequence of lower investments which may have had a constraining effect on the supply capacity of the economy and hence on potential output growth in the longer run.

Reference [83], applying model simulations (EAGLE model ${ }^{7}$ ), investigates the effect of a temporary increase in public investment in a large euro area country (Germany), focusing on: 1) output and 2) public finances. They found that an investment shock equal to $1 \%$ of GDP over 20 quarters, financed through public debt, implies a positive impact equal to: 1) 1.7 on GDP for Germany; 2) less than 0.1 on GDP for Rest of Euro Area. Other empirical results are the followings: 1) the longer-term positive effects on the economy's potential output and 2) the evidence that impact on public finances crucially depend on the effectiveness of investment and the productivity of public capital ${ }^{8}$. If they are low, an increase in public investment is associated with a greater deterioration of the debt outlook and less persistent output gains. This study concludes that any increase in public investment needs to be assessed in the light of its productivity, its financing and the relative costs and benefits of the financing options. Then economic consid-

\footnotetext{
${ }^{7}$ For technical details: Gomes et al. [84].

${ }^{8}$ At this regard other literature is focusing on estimate optimal public capital stock to GDP ratios, under the assumption that the marginal returns of public capital are decreasing. Reference [85] shows that in the United States, the optimal capital stock is about 60\% of GDP; Kamps [67] finds an optimal capital stock around $40 \%$ in European countries and more recently, Checherita-Westphal et al. [86] find that the optimal public capital stock level in OECD countries is between 50\% and $80 \%$ of GDP.
} 
erations are important for ensuring a rigorous selection of productive investment projects (ECB [83]).

Another interesting empirical paper is presented by Mourougane et al. [87]. Using F\&F, FM and NiGEM structural macro-econometric models ${ }^{9}$, they show results of a set of simulations suggesting that raising public investment rises business investment in the most advanced economies after one year and, with corresponding increases in the business sector capital stock and potential output. Moreover if the additional public investment is concentrated in network industries these positive effects could be even stronger, in particular in European Union where there is a greater possibility of crowding in private investment. In the simulations, the long-term impact of a permanent investment increase on the productive capacity of the economy produces: 1) a direct effect on capital accumulation in the production function and 2) some spillover effects from the higher public capital stock on potential output. The authors show also that combining an investment stimulus with structural reform enhances growth impacts and it accentuates the reduction of the public debt-to-GDP ratio. In particular the implementation of product-market reforms can enhance the impact of an investment-led stimulus on growth and public finances, through their impact on total factor productivity and potential output. By increasing potential output in the long run, a product market reform package reduces uncertainties surrounding public debt, especially in the most indebted European countries.

Reference [88] analyze the sectorial and regional effects of infrastructure investments in Portugal. Applying a VAR model, they identify areas of infrastructures investments with virtuous economic and budgetary effects. At this regards their results show that investments in transportation infrastructures (railroads, ports and airports) and in social infrastructures (health and education infrastructures) should be considered as priority investments also because they will pay for themselves in the form of long term enhanced tax revenues under rather reasonable effective tax rates. Reference [89] - applying the same methodologies and focusing on data of 4 Member States (France, Germany, Italy and Spain)-obtain similar results. They find that infrastructure investment not only drives positive demand shock but also raises factor productivity. Moreover they find that infrastructure investment has a higher impact on activity in economic bad times than in economic normal times. Consequently infrastructure investment is highly recommendable as policy lever to augment GDP and reduce the public debt burden. The general conclusions of their work are the following: 1) infrastructure investment has very large positive effects on the economic performance of Euro area countries and 2) a very large infrastructure multiplier for the euro area sug${ }^{9}$ The structural macro-econometric models can be considered more faithful to the Keynesian paradigm. Most of them combine Keynesian reactions in the short run with neoclassical features in the long run. They usually lead to multipliers larger than 1 through crowding-in effects on private consumption or investment, depending on the monetary and foreign trade regime. For further details: Mourougane et al. [87]. 
gests that infrastructure investment is likely to pay for itself.

Using a NiGEM model Fic and Portes [90] quantify the macroeconomic impacts of investment in infrastructure in the UK. In particular, they look at the impacts on output, potential output, unemployment and fiscal balances, distinguishing between normal times and crisis periods (i.e. abnormal monetary and credit conditions). The authors find that increasing infrastructure investment in the UK has the potential to boost growth both in the short (defined as the first two years after the shock) and long run (defined as eight to sixteen years after the shock) and the impacts are even stronger in a crisis period as compared to normal times. The simulations show that an increase in infrastructure spending of $1 \%$ of GDP results in an increase about $1 \%$ of GDP in short run, and increases potential GDP by about $0.2 \%$ in the long run.

Another branch of empirical literature, that studies the effects of additional infrastructure spending, considers the production function approach (Núñez-Serrano and Velázquez [91]; Agénor and Neanidis [92]; Bom and Ligthart [93]; Romp and De Hann [72]). This approach studies the technical relationship between public capital and other production factors on the one hand, and output on the other. In other words, a public capital stock is often incorporated as an additional production factor, next to a private capital stock and labor, by augmenting the production function. The empirical works generally assume that public capital forms an element in the macroeconomic production function and enters in two ways (directly as a third input in production function and indirectly by means of multifactor productivity). According to Pereira and Andraz [94] the positive contribution of public capital increases to growth shows a decline over time, especially in developed countries, because of a downward trend in the marginal productivity of public capital which determines gains for additional investment smaller than in the past. When the public capital stock is allowed to degrade through lack of investment, this could in theory lead to slower private-sector productivity growth. However Bivens [95] states that improving private-sector productivity is just one reason to support expanded public investment. He sustains that also when public investments do not affect private-sector productivity, they produce always a benefit if it allows to delivery more efficiently public goods. For example if people receive clean water and air, safe food and medicine, and transportation services for less money than they spend currently, this is a perfect way to enjoy the economic returns to expanded public investment, even if they do not boost private-sector productivity. Moreover another reason to support expanded public investment consists in the possibility that its benefits are more broadly shared than the benefits of private-sector investment. The general conclusion of this strand of the literature is that public capital-and in particular investment in core infrastructure (Bom and Ligthart [93]) - supports the GDP as well as potential output. The empirical results on positive effects of public investment differ across countries, regions, and sectors (Bom and Lighart [93]; Núñez-Serrano and Velázquez [91]). 


\section{Conclusions}

This theoretical discussion argues on some issues on potential output because they have important policy implications. The starting point was the analysis of the economic theory about the relation between potential output, inflation and unemployment. In doing so I emphasized as the theoretical assumptions have not been proven by empirical evidence on the last decade. In particular, the most important empirical results are the following: 1) the concept of potential output defined as the level of national income compatible with the natural rate of unemployment is not validated, then it is necessary to better investigate the relationships underlying the concept; 2) the so called "divine coincidence", according to which stabilizing inflation is equivalent to stabilizing the welfare-relevant output gap, does not happen, 3) monetary policy might not be successful, 4) the relation between the level of unemployment and the level of inflation is weak and it looks like the old downward sloping Phillips Curve, and 5) the persistent (hysteresis) effect of cyclical fluctuations can origin by supply and demand shocks (also positive).

In add at this divergence between theory and empirical evidence, there are also technical issues concerning the methods to estimate potential output. The measurement of potential output is not observable, and it depends on models and assumptions applied to estimate it. At this regards the existing methods present some weaknesses reducing reliability of the estimation results.

These issues should be adequately taken into account by decision makers when defining economic policy in particular in the actual secular stagnation scenario. Until today it is not clear to what extent potential output growth has been affected by the recent crisis. The actual stabilization policies-based on the existence of output gaps and on public debt sustainability-might be not able to mitigate effectively cyclical fluctuations and to stimulate economic growth. Looking at potential output of two advanced economies, as the United States and Euro area, it seems to recover in the US while in Euro area it is still sluggish. At this regards, academics and some policy makers have criticized both tight fiscal rules of SGP and TSGC (which are closely related to the concept of potential output and NAIRU) and the related austerity measures implemented by Member States in order to respect them. Recent empirical evidence shows that those measures worsened economic situation. In particular some authors argue about "negative loop" determined as a consequence of the interaction between an overly pessimistic view on potential output among policy makers and the effect of fiscal policy focused mainly on contractionary measure.

This theoretical analysis emphasized an economic literature that discusses an alternative way to use fiscal policy on the basis of positive relation between infrastructure spending and economic growth. The main conclusion is that an increase of public capital affects positively economic growth. In other words, an increase of public spending and in particular additional infrastructure spending can rise GDP as well as potential output. To deepen the discussion I looked at 
empirical works focused on Euro area which confirm this positive relation.

At the end of this analysis, the following advices emerge: 1) to take with caution the actual measure of potential output given the weaknesses of the existing methods to estimate it and the higher uncertainty on its underlying relationships i.e. the origin of cyclical fluctuations; 2) to consider fiscal stimulus as a policy option potentially effective; 3 ) to inform adequately policy makers (at national and international level) about the net benefits to implement another fiscal policy, based on additional infrastructure spending; and 4) to consider as preconditions for a good infrastructure spending, the followings: a) appropriate institutional governance, that for what concerns Euro area implies a better coordination of national fiscal policies and b) selection of sound investment projects, through robust evaluation methods.

\section{Conflicts of Interest}

The author declares no conflicts of interest regarding the publication of this paper.

\section{References}

[1] Jahan, S. and Mahmud, A.S. (2013) What Is the Output Gap? Economists Look for the Difference between What an Economy Is Producing and What It Can Produce. Finance \& Development, IMF, Washington DC.

[2] Okun, A. (1962) Potential GNP: Its Measurement and Significance. The Political Economy of Prosperity, Proceedings of ASA, Washington DC, Cowles Foundation Paper, 190.

[3] Okun, A. (1983) Economics for Policy Making. MIT Press Cambridge, London.

[4] Hauptmeier, S., Sánchez-Fuentes, A.J. and Schuknecht, L. (2011) Towards Expenditure Rules and Fiscal Sanity in the Euro Area. Journal of Policy Modeling, 33, 597-617. https://doi.org/10.1016/j.jpolmod.2011.03.006

[5] Phillips, A.W. (1958) The Relation between Unemployment and the Rate of Change of Money Wage Rates in the United Kingdom, 1861-1957. Economica, 100, 283 299. https://doi.org/10.2307/2550759

[6] Samuelson, P.A. and Solow, R.M. (1960) Analytical Aspects of Anti-Inflation Policy. The American Economic Review, 2, 177-194.

[7] Phelps, E.S. (1967) Phillips Curves, Expectations of Inflation and Optimal Unemployment over Time. Economica, 135, 254-281. https://doi.org/10.2307/2552025

[8] Friedman, M. (1968) The Role of Monetary Policy. The American Economic Review, 1, 1-17.

[9] Stirati, A. (2016) Blanchard, the NAIRU, and Economic Policy in the Eurozone. Institute for New Economic Thinking, New York. https://www.ineteconomics.org/perspectives/blog/blanchard-the-nairu-and-econo mic-policy-in-the-eurozone

[10] Blanchard, O. (2016) The US Phillips Curve: Back to the 1960s? Peterson Institute for International Economics, Washington DC, Policy Brief, 16-1, January.

[11] Gordon, R.J. (1997) The Time-Varying NAIRU and Its Implications for Economic Policy. Journal of Economic Perspectives, 1, 11-32.

https://doi.org/10.1257/jep.11.1.11 
[12] Blanchard, O. and Summers, L. (1986) Hysteresis and European Unemployment Problem. In: Fischer, S., Ed., NBER Macroeconomics Annual, MIT Press, Cambridge, 15-77. https://doi.org/10.1086/654013

[13] Pichelmann, K. and Schuh, A.U. (1997) The NAIRU Concept: A Few Remarks. Economics Department Working Papers, No. 178, OCDE/GD(97), Paris, 89.

[14] Baker, D., Glyn, A., Howell, D. and Schmitt, J. (2005) Labour Market Institutions and Unemployment: Assessment of the Cross-Country Evidence. In: Howell, Ed., Fighting Unemployment. The Limits of Free Market Orthodoxy, Oxford University Press, Oxford, 72-118.

[15] Delong, J.B. and Summers, L.H. (2012) Fiscal Policy in a Depressed Economy. Brookings Papers on Economic Activity, 44, 233-297. https://doi.org/10.1353/eca.2012.0000

[16] International Monetary Fund (2012) United Kingdom 2012 Article IV Consultation. http://www.imf.org/external/pubs/ft/scr/2012/cr12190.pdf https://doi.org/10.5089/9781475542004.002

[17] Blanchard, O., Cerutti, E. and Summers, L. (2015) Inflation and Activity-Two Explorations and Their Monetary Policy Implications. IMF Working Paper, WP/15/230, November. https://doi.org/10.5089/9781513536613.001

[18] Blanchard, O.J. (1986) Comments and Discussion on Investment, Output and the Cost of Capital. Brookings Papers on Economic Activity, 1, 153-158. https://doi.org/10.2307/2534415

[19] Chirinko, R.S. (1993) Business Fixed Investment Spending: Modelling Strategies, Empirical Results and Policy Implications. Journal of Economic Literature, 31, 1875-1911.

[20] Ford, R. and Poret, P. (1990) Business Investments in OECD Economies: Recent Performance and Some Implications for Policy. OECD Economic Department Working Papers, 88.

[21] Khotari, S.P., Lewellen, J. and Warner, J.B. (2014) The Behaviour of Aggregate Corporate Investment. MIT Sloan School Working Paper, No. 5, 112-114. https://doi.org/10.2139/ssrn.2511268

[22] Sharpe, S.A. and Suarez, G.A. (2014) The Insensitivity of Investment to Interest Rates: Evidence from a Survey of CFOs. Finance and Economics Discussion Series (FEDS) 2, Divisions of Research \& Statistics and Monetary Affairs Federal Reserve Board, Washington DC. https://doi.org/10.17016/FEDS.2014.02

[23] Girardi, D. and Pariboni, R. (2016) Long-Run Effective Demand in the US Economy: An Empirical Test of the Sraffian Supermultiplier Model. Review of Political Economy, 28, 523-544. https://doi.org/10.1080/09538259.2016.1209893

[24] Onaran, Ö. and Galanis, G. (2012) Is Aggregate Demand Wage Led or Profit Led? National and Global Effects. ILO Conditions of Work and Employment Series, Vol. 31 .

[25] Schoder, C. (2014) Effective Demand, Exogenous Normal Utilization and Endogenous Capacity in the Long Run: Evidence from a Cointegrated Vector Autoregression Analysis for the USA. Metroeconomica, 65, 298-320. https://doi.org/10.1111/meca.12041

[26] Wen, Y. (2007) Granger Causality and Equilibrium Business Cycle Theory. Federal Reserve Bank of St. Louis Review, St. Louis, 195-205. https://doi.org/10.20955/r.89.195-206

[27] Martin, R., Teyanna, M. and Wilson, B.A. (2015) Potential Output and Recessions: 
Are We Fooling Ourselves? Board of Governors of the Federal Reserve System, International Finance Discussion Papers, No. 1145.

https://doi.org/10.17016/IFDP.2015.1145

[28] Ball, L., Mankiw, N.G. and Nordhaus, W.D. (1999) Aggregate Demand and Long-Run Unemployment. Brookings Papers on Economic Activity, 2, 189-251. https://doi.org/10.2307/2534680

[29] Ball, L. (2009) Hysteresis in Unemployment: Old and New Evidence (No. w14818). National Bureau of Economic Research, Cambridge. https://doi.org/10.3386/w14818

[30] Ball, L. (2014) Long-Term Damage from the Great Recession in OECD Countries (No. w20185). National Bureau of Economic Research, Cambridge. https://doi.org/10.3386/w20185

[31] Cerra, V. and Saxena, S.C. (2009) Growth Dynamics: The Myth of Economic Recovery. The American Economic Review, 98, 439-457. https://doi.org/10.1257/aer.98.1.439

[32] Fatás, A. and Summers, L.H. (2016) The Permanent Effects of Fiscal Consolidations (No. w22374). National Bureau of Economic Research, Cambridge. https://doi.org/10.3386/w22374

[33] Reifschneider, D., Wascher, W. and Wilcox, D. (2015) Aggregate Supply in the United States: Recent Developments and Implications for the Conduct of Monetary Policy. IMF Economic Review, 63, 71-109. https://doi.org/10.1057/imfer.2015.1

[34] Fazzari, S.M., Ferri, P. and Greenberg, E. (1998) Aggregate Demand and Firm Behavior: A New Perspective on Keynesian Microfounfations. Journal of Post Keynesian Economics, 20, 527-558. https://doi.org/10.1080/01603477.1998.11490167

[35] Gali, J. (1999) Technology, Employment, and the Business Cycle: Do Technology Shocks Explain Aggregate Fluctuations? The American Economic Review, 89, 249-271. https://doi.org/10.1257/aer.89.1.249

[36] Lorentz, A. (2004) Sectoral Specialisation and Growth Rate Differences Among Integrated Economies, LEM Working Paper Series 06, Laboratory of Economics and Management Sant'Anna School of Advanced Studies, Pisa, March.

[37] Girardi, D., Paternesi-Meloni, W. and Stirati, A. (2017) Persistent Effects of Autonomous Demand Expansions. Institute for New Economic Thinking Working Paper Series No. 70. https://doi.org/10.2139/ssrn.3125213

[38] Girardi, D., Paternesi-Meloni, W. and Stirati, A. (2018) When Demand Shapes Supply. Institute for New Economic Thinking, New York. https://www.ineteconomics.org/perspectives/blog/when-demand-shapes-supply

[39] Summers, L.H. (2014) U.S. Economic Prospects: Secular Stagnation, Hysteresis, and the Zero Lower Bound. Business Economics, 49, 65-73.

https://doi.org/10.1057/be.2014.13

[40] Teulings, C. and Baldwin, R. (2014) Secular Stagnation: Facts, Causes and Cures. Centre for Economic Policy Research, London.

[41] Guajardo, J., Leigh, D. and Pescatori, A. (2014) Expansionary Austerity? International Evidence. Journal of the European Economic Association, 12, 949-968. https://doi.org/10.1111/jeea.12083

[42] Jordà, O. and Taylor, M. (2015) The Time for Austerity: Estimating the Average Treatment Effect of Fiscal Policy. The Economic Journal, 126, 219-255. https://doi.org/10.1111/ecoj.12332

[43] Blanchard, O., Dell'Ariccia, G. and Mauro, P. (2010) Rethinking Macroeconomic 
Policy. IMF Staff Position Note, February. https://doi.org/10.5089/9781455224982.004.A001

[44] Summers, L.H. (2015) Demand Side Secular Stagnation. The American Economic Review, 105, 60-65. https://doi.org/10.1257/aer.p20151103

[45] Turner, A. (2015) The Case for Monetary Finance-An Essentially Political Issue. IMF 16th Jacques Polak Annual Research Conference, Washington DC, 5-6 November 2015, 1-54.

[46] Furman, J. (2016) The New View of Fiscal Policy and Its Application. Conference: Global Implications of Europe's Redesign, New York, October 2016, 1-22.

[47] International Monetary Fund (2015) Private Investment: What's the Holdup? World Economic Outlook, Ch. 4.

[48] OECD (2015) Lifting Investment for Higher Sustainable Growth. OECD Economic Outlook, No. 1, Ch. 3, OECD Publishing, Paris.

[49] European Parliament (2017) Potential Output Estimates and Their Role in the EU Fiscal Policy Surveillance. Briefing, Directorate-General for Internal Policies. http://www.europarl.europa.eu/RegData/etudes/BRIE/2016/574407/IPOL BRI(2016 $\lcm{574407 \text { EN.pdf }}$

[50] Hodrick, R.J. and Prescott, E.C. (1997) Postwar U.S. Business Cycles: An Empirical Investigation. Journal of Money, Credit, and Banking, 29, 1-16.

https://doi.org/10.2307/2953682

[51] Baxter, M. and King, R.G. (1999) Measuring Business Cycles: Approximate Bandpass Filters. The Review of Economics and Statistics, 81, 575-593. https://doi.org/10.1162/003465399558454

[52] Anderton, R., Aranki, T., Dieppe, A., Elding, C., Haroutunian, S., Jacquinot, P., Jarvis, V., Labhard, V., Rusinova, D. and Szörfi, B. (2014) Potential Output from a Euro Area Perspective. ECB, Occasional Paper Series, No. 156, November.

[53] Cotis, J., Elmeskov, J. and Mourougane, A. (2008) Estimates of Potential Output: Benefits and Pitfalls from a Policy Perspective. OECD Economics Department, Mimeo.

[54] Beveridge, S. and Nelson, C.R. (1981) A New Approach to Decomposition of Economic Time Series into Permanent and Transitory Components with Particular Attention to Measurement of the Business Cycle. Journal of Monetary Economics, 7, 151-174. https://doi.org/10.1016/0304-3932(81)90040-4

[55] Blanchard, O.J. and Quah, D. (1989) The Dynamic Effects of Aggregate Demand and Aggregate Supply. The American Economic Review, 79, 655-673.

https://doi.org/10.3386/w2737

[56] Harvey, A. (1989) Forecasting, Structural Time Series Models and the Kalman Filter. Cambridge University Press, Cambridge. https://doi.org/10.1017/CBO9781107049994

[57] Havik, K., et al. (2014) The Production Function Methodology for Calculating Potential Growth Rates \& Output Gaps. Economic Papers, No. 535, Directorate-General for Economic and Financial Affairs, European Commission.

[58] Ufficio Parlamentare di Bilancio (2015) La stima dell'output potenziale e dell'output gap: Analisi di alcune criticità. Ufficio Parlamentare di Bilancio, Nota di lavoro, 1.

[59] Epstein, N. and Machiarelli, C. (2010) Estimating Poland's Potential Output-A Production Function Approach. IMF Working Paper, No. 15. https://doi.org/10.5089/9781451962093.001

[60] Konuki, T. (2008) Estimating the Potential Output and the Output Gap in Slovakia. 
IMF Working Paper, No. 275. https://doi.org/10.5089/9781451871333.001

[61] Coibion, O., Gorodnichenko, Y. andUlate, M. (2017) The Cyclical Sensitivity in Estimates of Potential Output. NBER Working Paper, No. 23580.

https://doi.org/10.3386/w23580

[62] Economic Policy Committee (2001) Report on Potential Output and Output Gap. Brussels. https://ec.europa.eu/economy finance/publications/pages/publication6586 en.pdf

[63] Deutsche Bundesbank (2014) On the Reliability of International Organisations' Estimates of the Output Gap. Monthly Report, No. 66, 4, April.

[64] Blanchard, O. and Giavazzi, F. (2004) Improving the SGP through a Proper Accounting of Public Investment. CEPR Discussion Paper, No. 4220.

[65] Hakhu, A.B., Piergallini, A. and Scaramazzino, P. (2014) Public Capital Expenditure and Debt Dynamics: Evidence from the European Union. Centre for Financial \& Management Studies, SOAS, University of London, London.

[66] Aschauer, D.A. (1989) Is Public Expenditure Productive? Journal of Monetary Economics, 23, 177-200. https://doi.org/10.1016/0304-3932(89)90047-0

[67] Kamps, C. (2005) The Dynamic Effects of Public Capital: VAR Evidence for 22 OECD Countries. International Tax and Public Finance, 12, 533-558. https://doi.org/10.1007/s10797-005-1780-1

[68] Kamps, C. (2006) New Estimates of Government Net Capital Stocks for 22 OECD Countries 1960-2001. IMF Staff Papers, 53, 120-150.

[69] International Monetary Fund (2014) Is It Time for an Infrastructure Push? The Macroeconomic Effects of Public Investment. In: Abiad, A., et al., Eds., World Economic Outlook, Legacies, Clouds, Uncertainties, International Monetary Fund, Washington DC, Ch. 3, 75-114. https://doi.org/10.5089/9781484372265.081

[70] De Jong, J., Ferdinandusse, M. and Funda, J. (2018) Public Capital in the 21st Century: As Productive as Ever? Applied Economics, 50, 5543-5560. https://doi.org/10.1080/00036846.2018.1487002

[71] Fournier, J. (2016) The Positive Effect of Public Investment on Potential Growth. Working Papers, No. 1347, OECD Economics Department, OECD Publishing, Paris.

[72] Romp, W.E. and De Haan, J. (2005) Public Capital and Economic Growth: A Critical Survey. EIB Papers, 10, 41-70.

[73] Gaspar, V., Obstfeld, M. and Sahay, R. (2016) Macroeconomic Management When Policy Space Is Constrained: A Comprehensive, Consistent and Coordinated Approach to Economic Policy. IMF Staff Discussion Note. https://doi.org/10.5089/9781475537543.006

[74] Krugman, P.R. (1991) Increasing Returns and Economic Geography. Journal of Political Economy, 99, 483-499. https://doi.org/10.1086/261763

[75] Holtz-Eakin, D. and Lovely, M.E. (1996) Scale Economics, Returns to Variety, and the Productivity of Public Infrastructure. Regional Science and Urban Economics, 26, 105-123. https://doi.org/10.1016/0166-0462(95)02126-4

[76] Venables, A.J. (1996) Equilibrium Locations of Vertically Linked Industries. International Economic Review, 37, 341-359. https://doi.org/10.2307/2527327

[77] Fujita, M., Krugman, P.R. and Venables, A.J. (1999) The Spatial Economy. MIT Press, Cambridge. https://doi.org/10.7551/mitpress/6389.001.0001

[78] Warner, A.M. (2014) Public Investment as an Engine of Growth. IMF Working Paper, No. 14, 148. https://doi.org/10.5089/9781498378277.001 
[79] Berg, A., et al. (2015) Some Misconceptions about Public Investment Efficiency and Growth. IMF Working Paper, No. 15, 272.

https://doi.org/10.5089/9781513589978.001

[80] International Monetary Fund (2015) Making Public Investment More Efficient. Staff Report, International Monetary Fund, Washington DC. https://doi.org/10.5089/9781498344630.007

[81] Fatás, A. (2018) Fiscal Policy, Potential Output and the Shifting Goalposts. The Euro at 20 Conference, Dublin, 25-26 June 2018, 1-47.

[82] Fatás, A. and Summers, L.H. (2018) The Permanent Effects of Fiscal Consolidations. Journal of International Economics, 112, 238-250.

https://doi.org/10.1016/j.jinteco.2017.11.007

[83] European Central Bank (2016) Public Investment in Europe. ECB Economic Bulletin, No. 2, 1-14.

[84] Gomes, S., Jacquinot, P. and Pissani, M. (2009) EAGLE: A Model for Policy Analysis of Macroeconomic Interdependence in the Euro Area.

https://doi.org/10.2139/ssrn.1786417

[85] Aschauer, D.A. (2000) Do States Optimize? Public Capital and Economic Growth. The Annals of Regional Science, 34, 343-363.

https://doi.org/10.1007/s001689900016

[86] Checherita-Westphal, C., Hallett, A.H. and Rother, P. (2014) Fiscal Sustainability Using Growth maximizing Debt Targets. Applied Economics, 46, 638-647. https://doi.org/10.1080/00036846.2013.861590

[87] Mourougane, A., Botev, J., Fournier, J.M., Pain, N. and Rusticelli, E. (2016) Can an Increase in Public Investment Sustainably Lift Economic Growth? Working Papers, No. 1351, OECD Economics Department.

[88] Pereira, A. and Pereira, R. (2015) Infrastructure Investments in Portugal. Volume II: Essays on the Economic Effects of Infrastructure Investments in Portugal. Fundacao Francisco Manuel dos Santos.

[89] Broyer, S. and Gareis, J. (2013) How Large Is the Infrastructure Multiplier in the Euro Area? Flash Economics, Economic Research, No. 227, March.

[90] Fic, T. and Portes, J. (2013) Macroeconomic Impacts of Infrastructure Spending. Report to Trade Union Congress. National Institute of Economic and Social Research, London.

[91] Núñez-Serrano, J.A. and Velázquez, F.J. (2017) Is Public Capital Productive? Evidence from a Meta-Analysis. Applied Economic Perspectives and Policy, 39, 313 345.

[92] Agénor, P. and Neanidis, K. (2015) Innovation, Public Capital, and Growth. Journal of Macroeconomics, 44, 252-275. https://doi.org/10.1016/j.jmacro.2015.03.003

[93] Bom, P.R. and Ligthart, J.E. (2014) What Have We Learned from Three Decades of Research on the Productivity of Public Capital? Journal of Economic Surveys, 28, 889-916. https://doi.org/10.1111/joes.12037

[94] Pereira, A. and Andraz, J. (2013) On the Economic Effects of Public Infrastructure Investment: A Survey of the International Evidence. Journal of Economic Development, 38, 1-37. https://doi.org/10.35866/caujed.2013.38.4.001

[95] Bivens, J. (2017) The Potential Macroeconomic Benefits from Increasing Infrastructure Investment. Economic Policy Institute, Washington DC. 